\title{
Analisi Kelayakan Industri Deterjen Lerak dengan Menggunakan Financial Accounting
}

\author{
Uyuunul Mauidzoh ${ }^{1}$, Esa Rengganis S. ${ }^{2}$ \\ 12) Program Studi Teknik Industri, Sekolah Tinggin Teknologi Adisutjipto \\ Jl. Janti Blok R Lanud Adisutjipto \\ Email: penulis1@farahzizy@gmail.com, penulis2@esarengganisstta@gmail.com
}

\begin{abstract}
Abstrak. Patuk Detergen adalah pembersih sintetis campuran berbagai bahan, yang digunakan untuk membantu pembersihan dan terbuat dari bahan-bahan turunan minyak bumi. Yaitu senyawa kimia bernama alkyl benzene sulfonat (ABS) yang direaksikan dengan natrium hidroksida $(\mathrm{NaOH})$. Dibanding dengan sabun, detergen mempunyai keunggulan antara lain mempunyai dava cuci yang lebih baik serta tidak terpengaruh oleh kesadahan air. Akan tetapi penggunaan deterien secara terus menerus atau dalam jangka waktu lama akan menimbulkan dampak negatif bagilingkungan maupun ekosistemyang ada dis ekitar manusia.

Berdasarkan dampak negatif yang ditimbulkan karena penggunaan deterien maka perlu dicari bahan alami yang dapat menggantikan fungsi deterjen yang mengandung bahan-bahan yang berbahayabagi manusia maupun lingkungan hidup.

Dari perhitungan financial accounting diperoleh bahwa nilai waktu pengembalian modal (payback Period) selama 6,9 bulan, maka investasi dianggap layak untuk dilaksanakan. Sedangkan kriteria Net Present Value (NPV) memiliki nilai positif, yaitu sebesar Rp. 79.845.488. Kemudian untuk nilai Internal Rate of return dari investasi ini didapatkan hasil sebesar $37,22 \%$. Sedangkan untuk nilai Return on Investment yang didapat adalah sebesar $171,37 \%$. Dengan nilai tingkat pengembalian sebesar $71,37 \%$ investasi dianggap menguntungkan sehingga layak untuk dilaks anakan.
\end{abstract}

Kata kunci : Deterjen Lerak, Kelyakan Investasi, Financial Accounting, Payback Period, Internal Rate of Return, Net Present Value

\section{PENDAHULUAN}

Deterjen merupakan salah satu produk yang tidak bisa dipisahkan dari keperluan sehari-hari, terutama untuk mencuci pakaian maupun peralatan dapur. Deterjen yang ada di pasaran saat ini merupakan kombinasi bahan-bahan kimia yang berasal dari turunan minyak bumi seperti Fosfat dan Asetat. Limbah dari penggunaan deterjen yang terus menerus akan merusak lingkungan. Hampir seperempat limbar deterjen dihasilkan dari aktivitas mencuci.

Pohon Lerak atau Sapindus rarak de candole merupakan pohon dengan kualitas kayu yang setara dengan kayu jati, banyak tumbuh di Pulau jawa dan Sumatera. Biji Lerak mengandung saponin yang menghasilkan busa dan berfungsi sebagai bahan pencuci dan dapat pula dimanfaatkan sebagai pembersih peralatan dapur dan lantaitersebut karena mereka telah melihat potensinya.

Pada saat ini deterjen lerak di pasaran hanya tersedia dalam bentuk cair atau deterjen cair dan dikemas dalam botol ukuran $300 \mathrm{ml}$ atau 1 Liter. Dikarenakan sediaan berbentuk cairan, hal ini mengakibatkan para produsen deterjen lerak untuk mengirimkan produk yang mereka hasilkan keluar daerah. Mayoritas ekspedisi menolak untuk mengirim paket atau kiriman dalam bentuk cair meskipun sudah dkemas dalam botol yang tertutup rapat. Seandainya ekspedisi X mau menerima untuk mengirimkan produk ini mereka akan memberikan syarat packaging atau pengepakan yang relatif rumit 
dan menimbulkan biaya yang relatif tinggi. Akibatnya harga deterjen Lerak menjadi tinggi dan hanya dikenal oleh para wisatawan yang datang ke daerah produsen deterjen Lerak. Berdasarkan hasil pengamatan pada produk deterjen Lerak yang beredar di pasaran dan hasil survei kesadaran terhadap produk-produk yang ramah lingkungan maka perlu dilakukan diversifikasi atau pengembangan produk deterjen Lerak cair ke dalam bentuk serbuk. Diharapkan dengan adanya sediaan dalam bentuk serbuk produk deterjen Lerak akan mudah dikenalkan dan dipasarkan ke luar Daerah Istimewa Yogyakarta dan Solo. Selain produk deterjen Lerak tersebut ramah lingkungan dampak positif yang diharapkan adalah mampu membuka peluang industri baru bagi masyarakat

\section{Metodologi Penelitian}

Untuk menganalisi kelayakan deterjen lerak ini digunakan metode Financial Accounting Analysis. Menurut Sunariyah "Investasi adalah penanaman modal untuk satu atau lebih aktiva yang dimiliki dan biasanya berjangka waktu lama dengan harapan mendapatkan keuntungan di masa-masa yang akan datang."

Terdapat beberapa kriteria penilaian kelayakan yang dapat digunakan pada Financial Acc ounting Method. Kriteria-kriteria tersebut adalah :

1. Payback Period (PP)

Kriteria ini mencoba mengukur seberapa cepat investasi bisa kembali. Karena itu satuan hasilnya bukan persentase. Tetapi satuan waktu (bulan, tahun, dan sebagainya). Karena model ini mengukur seberapa cepat suatu investasi bisa kembali, maka dasar yang dipergunakan adalah aliran kas (cash flow).

Rumus periode pengembalian jika arus kas per tahun jumlahnya berbeda

Payback Period $=\mathrm{n}+(\mathrm{a}-\mathrm{b}) /(\mathrm{c}-\mathrm{b}) \times 1$ tahun

Dimana :

$$
\begin{aligned}
& \mathrm{n}=\text { Tahun terakhir dimana jumlah arus kas masih belum bisa menutup } \\
& \quad \text { investasi mula-mula } \\
& \mathrm{a}=\text { Jumlah investasi mula-mula } \\
& \mathrm{b}=\text { Jumlah kumulatif arus kas pada tahun ke }-\mathrm{n} \\
& \mathrm{c}=\text { Jumlah kumulatif arus kas pada tahun ke } \mathrm{n}+1
\end{aligned}
$$

Rumus periode pengembalian jika arus kas per tahun jumlahnya sama

Payback Period=(investasi awal)/(arus kas) $\mathrm{x} 1$ tahun

- Periode pengembalian lebih cepat : layak

- Periode pengembalian lebih lama : tidak layak

- Jika usulan proyek investasi lebih dari satu, maka periode pengembalian yang lebih cepat yang dipilih

2. NPV (Nilai Bersih Sekarang)

Kriteria ini menghitung selisih antara nilai sekarang inventasi dengan nilai sekarang penerimaan-penerimaan kas bersih di massa yang akan datang. Untuk menghitung nilai sekarang tersebut perlu ditentukan terlebih dahulu tingkat bunga yang dianggap relevan. Pada perhitungan ini tingkat bunga yang dipakai adalah $14 \%$ (diambil dari rata-rata tingkat bunga bank). NPV merupakan net benefit yang telah didiskon dengan menggunakan social opportunity cost of capital sebagai diskon faktor.

Selain itu juga diperlukan data tentang perkiraan biaya investasi, biaya operasi, dan pemeliharaan serta perkiraan manfaat/benefit dari proyek yang direncanakan.

$\mathrm{NPV}=\mathrm{Ao}+\left(\mathrm{A}_{1} /(1+\mathrm{r})\right)$

Keterangan : 
Ao = nilai aw al investasi;

$\mathrm{A}_{1}=$ nilai penerimaan dari investasi;

$\mathrm{r}=$ tingkat suku bunga yang relevan

Kriteria untuk menerima atau menolak rencana investasi dengan metode NPV adalah sebagai berikut

1. NPV > 0 maka investasi yang dilakukan memberikan manfaat bagi

perusahaan maka proyek/investasi dapat di lanjutkan.

2. NPV < 0 maka investasi yang dilakukan akan mengakibatkan kerugian bagi perusahaan maka proyek investasi tidak dapat dilanjutkan.

3. $\mathrm{NPV}=0$ maka investasi yang dilakukan tidak mengakibatkan perusahaan untung ataupun merugi, Kalau proyek dilaksanakan atau tidak dilaksanakan tidak berpengaruh pada keuangan perusahaan. Keputusan harus ditetapkan dengan menggunakan kriteria lain misalnya dampak investasi terhadap positioning perusahaan.

\section{IRR (Internal Rate of Return)}

Internal Rate of Return atau IRR merupakan indikator tingkat efisiensi dari suatu investasi. Suatu proyek/investasi dapat dilakukan apabila laju pengembaliannya (rate of return) lebih besar dari pada laju pengembalian apabila melakukan investasi di tempat lain (bunga deposito bank, reksadana dan lain-lain).

Proyek yang mempunyai nilai IRR yang tinggi yang mendapat prioritas. Walaupun demikian pertimbangan untuk melaksanakan proyek tidak cukup hanya dengan IRR-nya saja, tetapi secara umum tingkat pengembaliannya (rate of return) harus lebih besar dari biaya oportunitas penggunaan dana. Jadi suatu proyek akan dilaksanakan dengan mempertimbangkan tingkat pengembalian (IRR) dan tingkat diskonto (i). Tingkat diskontodisebut juga sebagai external rate of return, merupakan biaya pinjaman modal yang harusdiperhitungkan dengan tingkat pengembalian investasi. Investor akan melaksanakan semuaproyek yang mempunyai IRR > i dan tidak melaksanakan investasi pada proyek yang harga IRR $<$ i.

$$
I R R=I_{r}+\frac{N P V I_{r}}{N P V I_{r}-N P V I_{t}} x\left(I_{t}-I_{r}\right)
$$

\section{Return On Investment}

ROI merupakan pengukuran kemampuan perusahaan secara keseluruhan didalam menghasilkan keuntungan dengan jumlah keseluruhan aktiva yang tersedia didalam perusahaan.

Faktor-faktor yang mempengaruhiReturn On Investment (ROI) adalah sebagai berikut :

1. Turnover operating assets (Tingkat perputaran aktiva yang digunakan untuk operasi, yaitu kecepatan berputarnyaoperating assets dalam suatu periode tertentu.)

2. Profit Margin, yaitu keuntungan operasi yang dinyatakan dalam prosentase dan jumlah penjualan bersih, profit margin ini mengukur tingkat keuntungan yang dapat dicapai oleh perusahaan dihubungkan dengan penjualan.

Besarnya ROI akan berubah kalau ada perubahan profit margin atauassets turnover, baik masing-masing atau kedua-duanya. Dengan demikian maka pimpinan perusahaan dapat menggunakan salah satu atau kedua-duanya dalam rangka usaha untuk memperbesar ROI.

Usaha mempertinggi ROI dengan memperbesar profit margin adalah bersangkutan dengan usaha untuk mempertinggi efisiensi disektor produksi, penjualan dan administrasi. Usaha mempertinggi ROI dengan memperbesarassets turn over adalah kebijaksanaan investasi dana dalam berbagai aktiva, baik aktiva lancar maupun aktiva tetap. Nilai ROI dapat dihitung dengan cara sebagai berikut :

$$
R O I=\frac{\text { Laba Bersih Sesudah Pajak }}{\text { TOtal Aktiva }} \times 100 \%
$$

\section{Hasil dan Pembahasan}

\section{Proses Pembuatan Sabun Lerak Dalam Bentuk Serbuk}


Produk sabun cuci lerak yang beredar di pasaran saat ini kebanyakan berbentuk cairan. Pada penelitian ini biji lerak diolah menjadi bentuk serbuk. Proses pembuatan biji lerak ke dalam bentuk serbuk adalah sebagai berikut :

1. Pembersihan buah lerak dari kotoran

Setelah dipetik dari pohon, buah lerak dibersikan dari kotoran-kotoran yang menempel pada buah tersebut. Ranting atau tangkai kecil sisa tempat menempelnya buah lerak pada dahan harus dihilangkan.

2. Pengeringan Tahap I

Setelah buah lerak bersih dari sisa-sisa ranting yang menempel, maka proses berikutnya adalah mengeringkan buah lerak tersebut. proses pengeringan bisa dilakukan dengan cara menjemur buah lerak dibaw ah sinar matahari langsung atau dikeringkan dengan menggunakan bantuan mesin oven supaya proses lebih cepat.

3. Mengeluarkan biji lerak

Setelah buah lerak setengah kering, biji lerak yang berwarna hitam dikeluarkan dari daging buah lerak.

4. Pencacahan buah lerak setengah kering

Setelah buah lerak dikeluarkan bijinya, proses berikutnya adalah pencacahan buah lerak setengah kering menjadi potongan-potongan kecil. Tujuan dari proses pencacahan ini suaya nanti mudah dihaluskan.

5. Pengeringan Tahap II

Setelah proses pencacahan buah lerak dikeringkan lagi dengan bantuan sinar matahari atau dengan menggunakan oven hingga benar-benar kering.

6. Penghalusan tahap I

Setelah buah lerak benar-benar kering maka tahap berikutnya adalah penghalusan. Penghalusan dilakukan dengan menggunakan mesin Grinder.

7. Penyaringan

Setelah buah lerak dihaluskan beberapa saat proses berikutnya adalah penyaringan. Tujuan penyaringan ini adalah untuk memisahkan buah lerak yang benar-benar sudah halus dengan buah lerak yang belum halus.

8. Penghalusan tahap II

Pada tahap penghalusan ke dua ini buah lerak yang belum halus kembali dihaluskan sampai mencapai hasil yang diinginkan.

9. Pengemasan

Setelah buah lerak diproses sampai menjadi serbuk proses berikutnya adalah pengemasan. Serbuk buah lerak dimasukkan kedalam pouch plastik transparan dan siap digunakan sebagai sabun cuci.

\section{Perencanaan dan Pengembangan Produk}

Langkah-langkah pengembangan produk yang akan dilakukan adalah sebagai berikut :

1. Mengumpulkan data produk sabun cuci lerak dan harga jual di pasaran.

2. Mengumpulkan data peralatan, mesin dan biaya yang dibutuhkan untuk produksi.

3. Melakukan studi kelayakan investasi berdasarkan mesin utama yang akan digunakan.

4. Menentukan harga jual produk.

Setelah harga jual produk diketahui, maka proses selanjutnya adalah melakukan Product Benchmarking yaitu membandingkan produk dengan produk serupa yang dihasilkan oleh perusahaan lain untuk mengetahui kekuatan dan kelemahan produk yang dibuat. Hasil akhir dari benchmarking ini nantinya dapat digunakan untuk menyusun strategi penjualan produk.

\section{Pengumpulan Data Kebutuhan Peralatan, Mesin dan Biaya Produksi}

1. Procurement Cost

Procurement Cost merupakan total semua pengadaan peralatan yang diinvestasikan untuk menunjang kegiatan bisnis. Biaya procurement ini dikeluarkan pada tahun pertama. Untuk 
mengolah daging buah lerak menjadi serbuk lerak terdapat beberapa peralatan dan mesin yang digunakan. Jenis peralatan dan mesin yang digunakan dapat dilihat pada tabel 1.

Tabel 1. Tabel Procurement Cost

\begin{tabular}{|c|l|r|}
\hline No & \multicolumn{1}{|c|}{ Jenis Biaya } & \multicolumn{2}{|c|}{ Jumlah } \\
\hline 1. & Rotary Dryer & Rp. 50.000 .000 \\
\hline 2. & Disk Mill Machine & Rp. 19.600 .000 \\
\hline 3. & Bed Sealer & Rp. 2.350 .000 \\
\hline & Total Procurement Cost & Rp. 71.950 .000 \\
\hline
\end{tabular}

2. Start Up Cost

Start Up Cost merupakan biaya yang harus dikeluarkan untuk mendukung kebutuhan operasional. Sama dengan procurement, start up cost biasanya dikeluarkan pada tahun-tahun pertama. Untuk kegiatan produksi ijin usaha, ijin BPOM, dan ijin edar sangat penting.

Tabel 2. Tabel Start Up Cost

\begin{tabular}{|c|l|cr|}
\hline No & \multicolumn{1}{|c|}{ Jenis Biaya } & \multicolumn{2}{|c|}{ Jumlah } \\
\hline 1 & Pengurusan Ijin Usaha & $\mathrm{Rp}$ & 500.000 \\
\hline 2 & Pengurusan Ijin BPOM & $\mathrm{Rp}$ & 800.000 \\
\hline 3 & Pengurusan Ijin Edar & $\mathrm{Rp}$ & 500.000 \\
\hline & Total Start Up Cost & $\mathrm{Rp}$. & 1.800 .000 \\
\hline
\end{tabular}

3. On Going Cost

On Going Cost merupakan biaya-biaya yang harus dikeluarkan pada saat produksi telah dilaksanakan. Biaya ini terdiri dari biaya perawatan dan penggantian komponen atau spare part.

Tabel 3. Tabel On Going Cost

\begin{tabular}{|c|l|c|c|}
\hline No & \multicolumn{1}{|c|}{ Jenis Biaya } & Tahun ke-1 & \multicolumn{2}{c|}{ Tahun ke-2 } \\
\hline 1 & Biaya Perawatan & Rp. 0 & Rp. 200.000 \\
\hline 2 & Penggantian Spare Part & & Rp. 200,000 \\
\hline & Total On Going Cost & Rp 0 & Rp. 400.000 \\
\hline
\end{tabular}

4. Biaya Produksi

Pada tahap berikutnya adalah perhitungan biaya produksi. Untuk industri skala rumahan direncanakan kapasitas produksi per bulannya adalah $200 \mathrm{~kg}$. Untuk membuat $200 \mathrm{~kg}$ serbuk lerak dibutuhkan kurang lebih daging lerak sebanyak $300 \mathrm{~kg}$. Untuk menghitung biaya produksimaka perlu dimasukkan komponen-komponen lain yang terlibat, sepertitenaga kerja, listrik, bahan tambahan, pengemasan dan administrasi

Tabel 4. Tabel Rincian Komponen Biaya Produksi

\begin{tabular}{|c|l|c|r|rr|}
\hline No & Komponen Produksi & Kebutuhan & Biaya & \multicolumn{2}{|c|}{ Jumlah } \\
\hline 1. & Buah Lerak & $300 \mathrm{~kg}$ & Rp. $10.000 / \mathrm{kg}$ & Rp. 3.000 .000 \\
\hline 2. & Tenaga Kerja & 3 Org & Rp. $1.500 .000 /$ org / bulan & Rp. 4.500 .000 \\
\hline 3. & Listrik & - & Rp. .500.000/ bulan & Rp. 500.000 \\
\hline
\end{tabular}




\begin{tabular}{|c|l|c|r|rr|}
\hline 4. & Bahan Tambahan & $1 \mathrm{Kg}$ & Rp. 22.000/ Kg & Rp. & 22.000 \\
\hline 5. & Packing & $500 \mathrm{pcs}$ & Rp. 500/pc & Rp. & 250.000 \\
\hline \multicolumn{3}{|c|}{ TOTAL } & Rp. & $\mathbf{8 . 2 7 2 . 0 0 0}$ \\
\hline
\end{tabular}

5. Harga Jual Produk

Berdasarkan perencanaan kapasitas produksi $200 \mathrm{~kg}$ per bulan, deterjen serbuk Lerak akan dikemas per 400 gram sehingga jumlah produk yang akan dipasarkan sebanyak 500 pcs. Untuk menentukan harga jual maka perlu ditetapkan tingkat laba atau keuntungan yang diinginkan. Besarnya tingkat laba yang diinginkan adalah sebesar $30 \%$.

Cara untuk menentukan harga jual per pc adalah sebagai berikut :

$$
\begin{aligned}
H J A & =\left(\frac{\text { Biaya produksi perbulan }}{\text { Jumlah produk yang dihasilkan }}\right) \times 1,3 \\
H J A & =\left(\frac{8.272 .000}{500}\right) X 1,3 \\
\mathrm{HJA} & =\text { Rp. } 21.507,-\approx \text { Rp. } 21.500,-
\end{aligned}
$$

Berdasarkan perhitungan biaya produksi, jumlah produk yang dihasilkan dan tingkat laba atau keuntungan yang diinginkan didapatkan bahwa produk deterjen Lerak kemasan 400 gram akan dijual dengan harga Rp. 21.500.-

\section{Analisa Kelayak an Investasi}

Setelah proses perhitungan biaya-biaya dan manfaat dilakukan, maka dilakukan analisa kelayakan dengan menggunaan metode Payback Periode, Net Present Value, dan Return On Investment. Secara

\begin{tabular}{|c|c|c|}
\hline No & Pengukuran & Jumlah \\
\hline 1. & Procurement Cost & Rp. 71.950 .000 \\
\hline 2. & Start Up Cost & 1.800 .000 \\
\hline 3. & On Going Cost & 400.000 \\
\hline 4. & Harga Jual per pack & 21.500 \\
\hline 5. & Jumlah Produk yang dihasilkan & $500 \mathrm{pcs}$ \\
\hline
\end{tabular}
ringkas perhitungan biaya-biaya dapat dilihat pada tabel berikut.

Tabel 5 Tabel Hasil Pengumpulan dan Pengolahan Data

a. Payback Period (PP)

Pada tahap ini akan dilakukan analisa PP, yaitu perhitungan berapa lama modal yang dikeluarkan akan kembali.

Total Investasi $=$ Procurement Cost + Start Up Cost + On Going Cost

$$
\begin{aligned}
& =\text { Rp. } 71.950 .000+\text { Rp. } 1.800 .000+\text { Rp. } 400.000 \\
& =\text { Rp. } 74.150 .000
\end{aligned}
$$

Perkiraan penjualan per bulan sebanyak 500 pcs dengan harga jual Rp. 21.500, maka besarnya total pendapatan per bulan atau total kas adalah sebagai berikut:

Total Kas $=$ Rp. $21.500 \times 500 \mathrm{pcs}$

$$
=\text { Rp. 10.750.000,- }
$$

Jika $P P=\frac{\text { Total Investasi }}{\text { Total Kas }} \times 1$ bulan

Maka $P P=\frac{R p .74 .150 .000}{R p .10 .750 .000} \times 1$ bulan

$$
=6,9 \text { bulan }
$$


b. NPV (Nilai Bersih Sekarang)

Untuk menghitung nilai bersih sekarang digunakan perkiraan total kas yang masuk setiap bulan, total investasi yang digunakan dan tingkat suku bunga yang berlaku. Besarnya tingkat suku bunga yang berlaku saat ini adalah 11,5\% / tahun .

(Sumber : Bank Mandiri).

Untuk menghitung perkiraan total kas yang masuk dihitung berdasarkan perkiraan penjualan produk yang laku.

Perkiraan Total Kas $=(2400 \times$ Rp. 21.500$)+(3000 \times$ Rp. 21.500$)+$

(3600 x Rp. 21.500)

$=$ Rp. 193.500 .000

Dengan $\mathrm{n}=3$ tahun, maka :

$\mathrm{NPV}=\frac{51.600 .000}{(1+0,115)}+\frac{64.500 .000}{(1+0,115)^{2}}+\frac{77.400 .000}{(1+0,115)^{3}}-74.150 .000$

$=$ Rp. 79.845 .488

\section{c. IRR (Internal Rate of Return)}

Untuk menghitung tingkat pengembalian maka nilai i yang digunakan sebagai pembanding adalah tingkat suku bunga pinjaman mikro, yaitu sebesar $16,5 \%$.

Tabel 6. Aliran Kas untuk i = 11\%

\begin{tabular}{|c|c|c|c|c|c|}
\hline Perkiraan Jumlah Produk Terjual & & Kas & $\mathrm{i}=11 \%$ & & Nilai Kas \\
\hline $2400 \mathrm{pcs} /$ tahun & $\mathrm{Rp}$ & 51.600 .000 & 0,9009 & $\mathrm{Rp}$ & 46.486 .440 \\
\hline $3000 \mathrm{pcs} /$ tahun & $\mathrm{Rp}$ & 64.500 .000 & 0,8116 & $\mathrm{Rp}$ & 52.348 .200 \\
\hline $3600 \mathrm{pcs} /$ tahun & $\mathrm{Rp}$ & 77.400 .000 & 0,7312 & $\mathrm{Rp}$ & 56.594 .880 \\
\hline $4800 \mathrm{pcs} /$ tahun & $\mathrm{Rp}$ & 103.200 .000 & 0,6587 & $\mathrm{Rp}$ & 67.977 .840 \\
\hline $6000 \mathrm{pcs} /$ tahun & $\mathrm{Rp}$ & 129.000 .000 & 0,5934 & $\mathrm{Rp}$ & 76.548 .600 \\
\hline \multicolumn{4}{|c|}{ Total PV } & $\mathrm{Rp}$ & 299.955 .960 \\
\hline \multicolumn{4}{|c|}{ Investasi Awal } & $\mathrm{Rp}$ & 74.150 .000 \\
\hline \multicolumn{4}{|c|}{ NPV } & $\mathrm{Rp}$ & 225.805 .960 \\
\hline
\end{tabular}

Tabel 7. Aliran Kas untuk $\mathrm{i}=12 \%$

\begin{tabular}{|c|c|c|c|c|c|}
\hline Jumlah Produk Terjual & & Kas & $\mathrm{i}=12 \%$ & & Nilai Kas \\
\hline $2400 \mathrm{pcs} /$ tahun & $\mathrm{Rp}$ & 51.600 .000 & 0,8928 & $\mathrm{Rp}$ & 46.068 .480 \\
\hline $3000 \mathrm{pcs} / \mathrm{tahun}$ & $\mathrm{Rp}$ & 64.500 .000 & 0,7971 & $\mathrm{Rp}$ & 51.412 .950 \\
\hline $3600 \mathrm{pcs} /$ tahun & $\mathrm{Rp}$ & 77.400 .000 & 0,7117 & $\mathrm{Rp}$ & 55.085 .580 \\
\hline $4800 \mathrm{pcs} /$ tahun & $\mathrm{Rp}$ & 103.200 .000 & 0,6355 & $\mathrm{Rp}$ & 65.583 .600 \\
\hline $6000 \mathrm{pcs} / \mathrm{tahun}$ & $\mathrm{Rp}$ & 129.000 .000 & 0,5674 & $\mathrm{Rp}$ & 73.194 .600 \\
\hline \multicolumn{4}{|c|}{ Total PV } & $\mathrm{Rp}$. & 291.345 .210 \\
\hline \multicolumn{4}{|c|}{ Investasi Awal } & $\mathrm{Rp}$. & 74.150 .000 \\
\hline \multicolumn{4}{|c|}{ NPV } & $\mathrm{Rp}$. & 217.195 .210 \\
\hline
\end{tabular}

Nilai IRR dapat dicari dengan jalan interpolasi 


$$
\begin{aligned}
& I R R=11 \%-223.805 .960 \frac{12 \%-11 \%}{217.195 .210-225.805 .960} \\
& I R R=37,22 \%
\end{aligned}
$$

dilaksanakan.

Dikarenakan nilai melebihi tingkat suku bunga pinjaman mikro maka investasi tersebut layak

\section{d. Return On Investment}

ROI merupakan pengukuran kemampuan perusahaan secara keseluruhan didalam menghasilkan keuntungan dengan jumlah keseluruhan aktiva yang tersedia didalam perusahaan.

\begin{tabular}{|c|c|c|c|c|c|c|c|c|}
\hline \multirow{2}{*}{$\frac{\text { Jumlah Produk Terjual }}{2400 \mathrm{pcs} / \text { tahun }}$} & \multicolumn{2}{|r|}{ Kas } & \multicolumn{2}{|c|}{ Laba Bersih } & \multicolumn{2}{|c|}{ Pajak } & \multicolumn{2}{|c|}{ Laba Bersih Sesudah Pajak } \\
\hline & $\mathrm{Rp}$ & 51.600 .000 & $\mathrm{Rp}$ & 15.480 .000 & $\mathrm{Rp}$ & 77.400 & $\mathrm{Rp}$ & 15.402 .600 \\
\hline $3000 \mathrm{pcs} /$ tahun & $\mathrm{Rp}$ & 64.500 .000 & $\mathrm{Rp}$ & 19.350 .000 & $\mathrm{Rp}$ & 96.750 & $\mathrm{Rp}$ & 19.253 .250 \\
\hline $3600 \mathrm{pcs} /$ tahun & $\mathrm{Rp}$ & 77.400 .000 & $\mathrm{Rp}$ & 23.220 .000 & $\mathrm{Rp}$ & 116.100 & $\mathrm{Rp}$ & 23.103 .900 \\
\hline $4800 \mathrm{pcs} / \mathrm{tahun}$ & $\mathrm{Rp}$ & 103.200 .000 & $\mathrm{Rp}$ & 30.960 .000 & $\mathrm{Rp}$ & 154.800 & $\mathrm{Rp}$ & 30.805 .200 \\
\hline $6000 \mathrm{pcs} / \mathrm{tahun}$ & $\mathrm{Rp}$ & 129.000 .000 & $\mathrm{Rp}$ & 38.700 .000 & $\mathrm{Rp}$ & 193.500 & $\mathrm{Rp}$ & 38.506 .500 \\
\hline \multicolumn{7}{|c|}{ TOTAL } & $\mathrm{Rp}$. & 127.071 .450 \\
\hline
\end{tabular}

Tabel 8. Keuntungan yang diperoleh

$$
R O I=\frac{127.071 .450}{74.150 .000} \times 100 \%=171,37 \%
$$

\section{Analisa Kelayak an Investasi}

Setelah dilakukan pengumpulan dan pengolahan data maka dilakukan sebuah analisa kelayakan berdasarkan hasil yng didapat. Analisa kelayakan investasi ini bertujuan untuk melihat apakah investasi yang akan ditanamkan layak dilakukan atau tidak, dimana pada analisa kelayakan melibatkan beberapa komponen biaya, yaitu biaya persiapan, biaya investasi, biaya operasional, dan biaya pemeliharaan dan perbaikan. Sedangkan kriteria penilaian kelayakan yang digunakan adalah Payback Period (PP), Net Present Value (NPV), Internal Rate of Return (IRR) dan Return On Investment (ROI).

Hasil pengumpulan dan pengolahan data yang digunakan sebagai dasar pengambilan

\begin{tabular}{|c|c|c|}
\hline No & Pengukuran & Jumlah \\
\hline 1 . & Procurement Cost & Rp. 71.950 .000 \\
\hline 2. & Start Up Cost & $\begin{array}{ll}\text { Rp. } & 1.800 .000 \\
\end{array}$ \\
\hline 3. & On Going Cost & 400.000 \\
\hline 4. & Total Investasi & Rp. 74.150 .000 \\
\hline 5. & Harga Jual per pack & 21.500 \\
\hline 6. & Jumlah Produk yang dihasilkan & 500 pcs / bulan \\
\hline 7. & Payback Period & 6,9 bulan \\
\hline 8. & Net Present Value & Rp. 79.845.488 \\
\hline
\end{tabular}
keputusan layak atau tidaknya investasi yang akan dilakukan dapat dilihat pada tabel berikut.

Tabel 9. Tabel Hasil Pengolahan Data 


\begin{tabular}{|c|l|r|}
\hline 9. & Internal Rate of Return & $37,22 \%$ \\
\hline 10. & Return on Investment & $171,37 \%$ \\
\hline
\end{tabular}

Berdasarkan hasil pengolahan data maka hasil analisa kelayakan investasi yang akan dilakukan pada produksi deterjen serbuk Lerak adalah sebagai berikut :

Tabel 10. Kelayakan Investasi

\begin{tabular}{|c|l|c|}
\hline No & \multicolumn{1}{|c|}{ Komponen Penilaian } & Keputusan \\
\hline 1. & Payback Period & Layak \\
\hline 2. & Net Present Value & Layak \\
\hline 3. & Internal Rate of Return & Layak \\
\hline 4. & Return on Investment & Layak \\
\hline
\end{tabular}

Berdasarkan nilai waktu penembalian modal selama 6,9 bulan, maka investasi dianggap layak untuk dilaksanakan karena waktu 6,9 bulan relatif pendek untuk sebuah investasi produksi. Sedangkan kriteria Net Present Value (NPV) memiliki nilai positif, yaitu sebesar Rp. 79.845.488. Keputusan investasi dengan menggunakan kriteria NPV akan dilaksanakan jika nilai NPV positif dan tidak dilaksanakan jika nilai NPV negatif.

Kemudian untuk nilai Internal Rate of return dari investasi ini didapatkan hasil sebesar 37,22 $\%$. Jika dibandingkan dengan nilai IRR pinjaman UKM maka investasi ini dianggap layak untuk dilaksanakan karena nilai IRR investasi lebih besar jika dibandingkan dengan nilai IRR pinjaman UKM. Jika nilai IRR investasi lebih kecil daripada IRR pinjaman UKM maka investasi tidak layak untuk dilaksanakan.

Sedangkan untuk nilai Return on Investment yang didapat adalah sebesar 171,37\%. Dengan nilai tingkat pengembalian sebesar 71,37\% investasi dianggap menguntungkan sehingga layak untuk dilaksanakan.

\section{Ucapan Terima Kasih}

Penulis mengucapkan terima kasih kepada Sekolah Tinggi Teknologi Adisutjipto Yogyakarta yang telah memberi dukungan finansial terhadap penelitian ini. Juga kepada bagian P3M STTA yang telah membantu tugas dosen untuk melaksanakan salah satu Tridharma perguruan tinggi.

\section{Daftar Pustak a}

[1] Karl, T, Ulrich, 2012, Product Design and Development, Mc. Graw Hill Companies

[2] Kasmir dan Jakfar, 2003, Studi Kelayakan Bisnis, Penerbit Kencana, Jakarta.

[3] M.S., Ma'arif, 2003, Teknik-teknik Kuantitatif Untuk Manajemen, Grasindo, Jakarta

[4] Marimin, 2004, Teknik dan Aplikasi Pengambilan Keputusan Kriteria Majemuk, Grasindo, Jakarta

[5] Nasution, Hakim, Anwar, 2006, Manajemen Industri, Andi Offset, Yogyakarta 
[6] Nurjanah, Santi, 2013, Studi Kelayakan Pengembangan Bisnis Pada PT. Dagang Jaya Jakarta.

[7] Pujawan, Nyoman, 2009, "Ekonomi Teknik", Guna Widya, Surabaya.

[8] Pandian, Satish, et all, 2013, Composite Performance Index for Sustainability, IOSR JESTFT, Volume 3.

[9] Suliyanto, 2011,"Studi Kelayakan Bisnis", Andi Publisher, Jakarta.

[10] Sujatmiko, Agus, 2012, Analisa Kelayakan Investasi Penambahan Alat Produksi Pada usaha Candra Convection Kudus.

[11] Susanto, Dwi, Tony, dkk, 2013, "Studi Kelayakan Investasi Perluasan Jaringan TV Kabel pada PT. XYZ Dengan Metode Cost \& Benefit Analysis", Semnas Sistem Informasi Indonesia "SESINDO".

[12] Wahyu, Aswin, 2012, Analisa Kelayakan Investasi Untuk Rencana Penambahan Mesin Laminasi Baru, Jombang.

[13] Wu, X, Harry, et all, 2007, Comparative Performance of Indian and Chinesse Manufacturing Industries, 1980 - 2004, Journal Special Conference of The International association for Research in Income \& Wealth On Transition Economies 